\title{
Jugular venous and arterial concentrations of serum S-100B protein in patients with severe head injury: a pilot study
}

\author{
Andreas Raabe, David K Menon, Sanjeeva Gupta, Marek Czosnyka, John D Pickard
}

\begin{abstract}
The objective of this study was to analyse the temporal course of the jugular venousarterial gradient of $S-100 B$ protein after severe head injury and the correlation between the absolute concentrations of serum S-100B protein and outcome, CT findings, and clinical variables.

Fifteen patients were included in this pilot study. All patients were treated according to a standard therapy protocol targeted to maintain cerebral perfusion pressure. The serum concentration of S-100 protein was measured daily for five consecutive days after injury by a monoclonal two site immunoluminometric assay. Nine patients showed favourable and six unfavourable outcome after 6 months with a mortality rate of $33 \%$ (five patients). The mean gradient between jugular venous and arterial blood was $8.2 \%(p<0.05)$. Patients showing an unfavourable outcome had significantly higher jugular venous or arterial S-100 values compared with those with a favourable outcome (jugular venous $S-100 B 2.78 \mu \mathrm{g} / 1$ $v 1.22 \mu \mathrm{g} / 1, \mathrm{p}<0.05$; arterial $\mathrm{S}-100 \mathrm{~B} 2.48$ $\mu \mathrm{g} / 1 v 1.19 \mu \mathrm{g} / 1, \mathrm{p}<0.05)$. All patients with an initial or secondary increase in $S-100 B$ value of $>2 \mu \mathrm{g} / 1$ were found to have an unfavourable outcome. S-100B was found to be an independent predictor of outcome after severe head injury. The persisting increase of S-100B for three to five days even in patients with favourable outcome and no signs of secondary insults might reflect continuing damage to the bloodbrain barrier or ongoing glial cell death. (F Neurol Neurosurg Psychiatry 1998;65:930-932)
\end{abstract}

Keywords: head injury; S-100 protein; outcome

Despite the appreciable recent progress in cerebral monitoring it remains difficult to quantify the extent of primary brain injury apart from defining the Glagow coma score or initial CT.

Previous studies have assessed the serum concentration of various brain enzymes including $\mathrm{LDH}, \mathrm{CPK}_{\mathrm{BB}}$, and neuron specific enolase and shown considerable overlap between different outcome groups.
A promising biochemical marker currently under investigation is S-100B protein (S100B), a member of the family of the calcium binding proteins found mainly in the cytosol of glial cells. The concept is that S-100B is released after glial cell damage and can be found in increased concentrations in CSF and serum. It is highly specific for lesions of the CNS, has a short half life of 2 hours, ${ }^{1}$ and can be measured in both arterial and venous serum.

Raised concentrations of serum S-100B have been reported in patients after minor head injury, ${ }^{23}$ stroke, ${ }^{4-6}$ and those patients who have undergone cardiac surgery and present with neurological complications after circulatory arrest or cardiopulmonary bypass..$^{7-10}$

In our pilot study we have focused on serum S-100B concentrations in patients after severe head injury. Our hypothesis was that S-100B is released from the site of injury which is leading to a measurable gradient of S-100B concentrations between the jugular venous and arterial blood. The objective of our pilot study was to investigate (1) the jugular venous and arterial concentration of S-100B, (2) the temporal course of $\mathrm{S}-100 \mathrm{~B}$ release that might provide information about ongoing brain cell damage, and (3) the correlation between serum S-100B concentrations and outcome, CT findings, and clinical variables.

\section{Material and methods}

Fifteen patients with severe head injury in whom a retrograde jugular venous catheter had been inserted were included in this prospective study. Glasgow coma scale score at admission ranged from 3 to 8 (median 5). Five patients were women and 10 were men. Age ranged from 17 to 61 (median 39) years.

All patients were treated according to a therapy protocol targeted at maintaining cerebral perfusion pressure. Multimodal neuromonitoring was used to prevent the occurrence of or to treat secondary insults. Recorded variables were arterial blood pressure (ABP), intracranial pressure (ICP), cerebral perfusion pressure (CPP), jugular venous oxygen saturation $\left(\mathrm{sjvO}_{2}\right)$, and cerebrovascular autoregulatory response to spontaneous changes in CPP. ${ }^{11}$ Clinical variables related to outcome were 
noted including Glasgow coma scale score, patients' age, sex, daily pupil reactivity, APACHE II score, and the presence of extracerebral injury.

Brain CT was analysed according to the classification of Marshall et $a l,{ }^{12}$ the number and volume of mass lesions, the presence of traumatic subarachnoid haemorrhage, and the type of haematoma. Volume measurements of hyperdense, hypodense, and mixed density lesions were made using Cavalieri's direct estimator method. ${ }^{13}$

Outcome was assessed at discharge and at 6 months using the Glasgow outcome scale. Outcome was dichotomised into favourable (good outcome, moderate disability) and unfavourable outcome (severe disability, vegetative state, death).

The data for clinical variables, CT, and outcome were obtained blinded from the results of S-100 analysis.

MEASUREMENT OF SERUM S-100B PROTEIN

Blood samples for S-100 were taken as soon as possible after admission to the neurosurgical critical care unit at the Addenbrooke's Hospital, University of Cambridge, and every 24 hours for five consecutive days. Two samples were taken simultaneously from the arterial and the jugular venous blood using preheparinised tubes. Blood samples were immediately centrifuged and serum was frozen to $-72^{\circ} \mathrm{C}$ and stored for analysis.

The serum concentration of S-100 protein was measured by a commercially available monoclonal two site immunoluminometric assay (LIA-mat Sangtec 100, AB Sangtec Medical, Bromma, Sweden). Using this new test, values $<0.135 \mu \mathrm{g} / \mathrm{l}$ were considered normal, values between $0.135 \mu \mathrm{g} / 1$ and 0.50 $\mu \mathrm{g} / \mathrm{l}$ were considered borderline, and values $\geqslant 0.5 \mu \mathrm{g} / \mathrm{l}$ were considered pathological.

\section{Results}

Of the 15 patients included in this study, nine showed a favourable (60\%) and six an unfavourable $(40 \%)$ outcome after 6 months with a mortality rate of $33 \%$ (five patients).

The first samples were drawn between 12 hours and 38 hours after injury. The concentration of S-100 protein in jugular venous blood (median $0.92 \mu \mathrm{g} / \mathrm{l}$, interquartile range $0.43-1.60 \mu \mathrm{g} / 1)$ was significantly higher than in arterial blood (median $0.85 \mu \mathrm{g} / \mathrm{l}$, interquartile range $0.41-1.40 \mu \mathrm{g} / \mathrm{l}, \mathrm{p}<0.005$, Wilcoxon matched pairs test). An average gradient of $8.2 \%$ was found between jugular venous and arterial blood, independent of the absolute concentration of S-100B. However, there was a marked scatter with interquartile values ranging from $-2 \%$ to $+12 \%$ (absolute values 0.02 $\mu \mathrm{g} / 1-0.14 \mu \mathrm{g} / \mathrm{l})$. The overall correlation between jugular venous and arterial $\mathrm{S}-100 \mathrm{~B}$ values was $r=0.98 \quad(p<0.001)$. This gradient was independent of CT findings such as the size of contusion, the CT grade, the ocurrence of traumatic subarachnoid haemorrhage, and the outcome after 6 months.

Despite the difference between jugular venous and arterial concentrations of S-100B

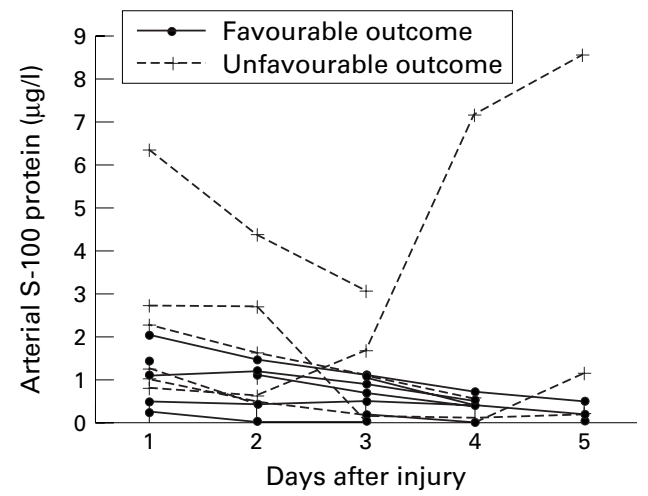

Time course of arterial S-100B in patients with favourable and unfavourable outcome after 6 months.

protein, the correlation with clinical variables and with outcome for both measurements was the same. Hence, the following results are given only for the arterial S-100B measurements.

Patients showing unfavourable outcome had significantly higher arterial S-100 values compared with those with favourable outcome $(\mathrm{p}<0.05$, Mann-Whitney $U$ test). All patients showing either an initial or a secondary increase in S-100B above $2 \mu \mathrm{g} / \mathrm{l}$ had an unfavourable outcome (positive predictive value $=1.0$, figure). An initial value of $S-100 \mathrm{~B}$ $<2$ without a secondary increase was associated with a favourable outcome in nine patients and with an unfavourable outcome in two patients (negative predictive value $=0.81$ ).

All patients with abnormal findings on CT showed increased concentrations of S-100, although numbers were too small to allow subgroup analysis.

\section{Discussion}

Recently Ingebrigtsen et al found a correlation between serum S-100B and postconcussion symptoms in 50 patients with minor head injury and normal CT. ${ }^{2}$ The same authors reported increased serum concentrations in four of 24 patients with minor head injury and normal CT. In two of those four patients contusions were visible on MRI. ${ }^{3}$ In patients with severe head injury they found increased S-100B values in all cases but no data were reported on the diagnostic and prognostic value of these findings. In another recent study of serum S-100B after severe head injury, initial concentrations were significantly higher in patients with unfavourable outcome compared with those with favourable outcome. However, outcome was only reported at discharge. ${ }^{14}$

The findings of our study indicate an association between neurological outcome after severe head injury and the serum concentration of S-100B protein. In this small cohort, S-100B was an independent predictor of outcome after severe head injury (table). All patients with either S-100B values of more than $2 \mu \mathrm{g} / 1$ or a secondary increase in S-100B subsequently had an unfavourable outcome. One patient who died showed a left temporal contusion of $18 \mathrm{~cm}^{3}$ and S-100B concentrations increased from initially $0.81 \mu \mathrm{g} / 1$ to 7.17 $\mu \mathrm{g} / \mathrm{l}$ at day 4 . At this time, there were no clinical or radiological signs of excessive ongoing 
Median values and interquartile range of clinical variables and $S-100 B$ concentrations in the different outcome groups

\begin{tabular}{llll}
\hline & Favourable outcome $n=9^{*}$ & & $\begin{array}{c}\text { Significance (p value) } \\
\text { Mann-Whitney U test }\end{array}$ \\
\hline Age (years) & $42(19-49)$ & $43(28-58)$ & 0.41 \\
GCS at admission & $6(5-8)$ & $3(3-5)$ & 0.19 \\
ICP $(\mathrm{mm} \mathrm{Hg})$ & $15(7-19)$ & $19(18-20)$ & 0.11 \\
$\mathrm{CPP}(\mathrm{mm} \mathrm{Hg})$ & $75(64-78)$ & $72(60-74)$ & 0.30 \\
APACHE II & $15(14-17)$ & $20(19-20)$ & $<0.01$ \\
Contusion volume $\left[\mathrm{cm}^{2}\right]$ & $6(0.5-26)$ & $15(11-76)$ & 0.36 \\
aS-100 $(\mu \mathrm{g} / \mathrm{l}) \dagger$ & $1.19(0.40-1.24)$ & $2.48(1.23-6.39)$ & $<0.05$ \\
jvS-100 $(\mu \mathrm{g} / \mathrm{l}) \dagger$ & $1.22(0.56-1.57)$ & $2.78(1.33-7.34)$ & $<0.05$ \\
\hline
\end{tabular}

${ }^{\star}$ Of the favourable outcome group ( $\left.n=9\right)$, CT was available only from six patients; thighest value.

aS-100 $=$ arterial S-100B, jvS-100 = jugular venous S-100B.

brain damage, vasospasm, or brain oedema or secondary insults with abnormal low CPP or high ICP and the cause of this increase remained unclear.

Because S-100B has a half life of 2 hours, increased values of $S-100 B$ released by the primary damage should return to baseline concentrations within 12-24 hours. Raised values for up to 5 days after injury might therefore reflect ongoing secondary brain damage. In patients showing a favourable outcome, the median time for the return of $S-100 B$ to concentrations $<0.50 \mu \mathrm{g} / 1$ was four days (72-120 hours).

We conclude that jugular venous and arterial concentrations of S-100B protein correlate with outcome after severe head injury but further studies are required. The time course of S-100B might be an additional biochemical variable for the assessment of ongoing secondary brain damage.

1 Usui A, Kato K, Abe T, et al. S-100ao protein in blood and urine during open-heart surgery. Clin Chem 1989;35:1942-4

2 Ingebrigtsen T, Romner B, Kongstad P, et al. Increased serum concentrations of protein S-100 after minor head serum concentrations of protein S-100 after minor head injury: a biochemical serum marker with prognostic valu

3 Ingebrigtsen T, Romner B. Serial S- 100 protein serum measurements related to early magnetic resonance imaging after minor head injury. Case report. F Neurosurg 1996;85: $945-8$
4 Kim JS, Yoon SS, Kim YH, et al. Serial measurement of interleukin-6, transforming growth factor-beta, and S-100 protein in patients with acute stroke. Stroke 1996;27:1553-

5 Persson L, Hardemark HG, Gustafsson J, et al. S-100 protein and neuron-specific enolase in cerebrospinal fluid and serum: markers of cell damage in human central nervous system. Stroke 1987;18:911-8.

6 Fagnart OC, Sindic CJ, Laterre C. Particle counting immunoassay of $\mathrm{S} 100$ protein in serum. Possible relevance in tumors and ischemic disorders of the central nervous system. Clin Chem 1988;34:1387-91.

7 Westaby S, Johnsson P, Parry AJ, et al. Serum S100 protein: a potential marker for cerebral events during cardiopulmonary bypass. Ann Thorac Surg 1996;61:88-92.

8 Taggart DP, Mazel JW, Bhattacharya K, et al. Comparison of serum S-100 beta levels during CABG and intracardiac operations. Ann Thorac Surg 1997;63:492-6.

9 Astudillo R, van der Linden J, Radegran K, et al. Elevated serum levels of S-100 after deep hypothermic arrest correlate with duration of circulatory arrest. Eur $\mathcal{F}$ Cardiothorac Surg 1996;10:1107-13.

10 Johnsson P, Lundqvist C, Lindgren A, et al. Cerebral complications after cardiac surgery assessed by S-100 and NSE levels in blood. F Cardiothorac Vasc Anesth 1995;9: 694-9.

11 Czosnyka M, Kirkpatrick PJ, Pickard JD. Multimodal monitoring and assessment of cerebral haemodynamic reserve after severe head injury. Cerebrovasc Brain Metab Rev 1996; 8:273-95.

12 Marshall LF, Marshall SB, Klauber MR, et al. A new classification of head injury based on computerized tomography. f Neurosurg 1991;75(suppl):S14-20.

13 Clatterbuck RE, Sipos EP. The efficient calculation of neurosurgically relevant volumes from computed tomographic scans using Cavalieri's direct estimator. Neurosurgery 1997; 40:339-42,43.

14 Woertgen C, Rothoerl RD, Holzschuh M, et al. Comparison of serial S-100 and NSE serum measurements after severe head injury. Acta Neurochir (Wien) 1997;139:1161-5. 